\title{
$\mathrm{FeCr}$ 系焼結磁性合金の交流磁気特性に及ぼす酸化物粉末添加の影響
}

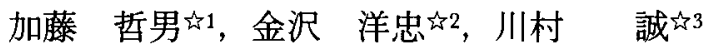 \\ 河野 富夫衫，草加 勝司游3
}

41 大同工業大学, $\mathbf{T} 457$ 名古屋市南区大同町2-21.

42 大同工業大学大学院, 干457 名古屋市南区大同町2-21.

吸 大同特殊鋼姝技術開発研究所, $\overline{\mathbf{T}} 457$ 名古屋市南区大同町2-30.

\section{Influence of the Added Oxide Powder on the Magnetic Property of the Iron-Chromium Magnetic Sintered Alloy in Alternating Field}

\author{
Tetsuo Kato ${ }^{\lceil 21}$, Hirotaka Kanazawa ${ }^{£ 2}$, Makoto Kawamura ${ }^{\hbar 3}$ \\ Tomio Kono ${ }^{\text {tr } 3}$ and Katsushi Kusaka ${ }^{23}$ \\ Daido Institute of Technology, 2-21 Daido-cho Minami-ku, Nagoya 457. \\ 42 Graduate School, Daido Institute of Technology, 2-21 Daido-cho Minato-ku, Nagoya 457. \\ th Res. and Dev. Lab., Daido Steel Co., 2-30 Daido-cho Minami-ku, Nagoya 457.
}

Received January 10, 1994

Effects of addition of the mixed oxide powder ( $\mathrm{SiO}_{2}, \mathrm{CaO}$ and $\mathrm{Al}_{2} \mathrm{O}_{3}$ ) on the magnetic properties of the low carbon $\mathrm{Fe}-13 \mathrm{Cr}-0.8 \mathrm{Si}$ sintered alloy were studied. The magnetic characteristics of samples in direct magnetic field degraded with addition of oxide powder, though that indicated to increase with rising the sintering temperature. On the contrary, the amplitude relative permeability of samples in alternating magnetic field was higher in the case of $0.1 \sim 0.2 \%$ addition of oxide powder than no addition one. Though the relative permeability showed a change of increase and then decrease with rising the sintering temperature, proportion of the decrease in the relative permeability at the higher sintering temperature was restrained by addition of the oxide powder. These phenomena were discussed in the relation of sintered density, porosity and electrical resistivity.

\section{1 まえがを}

FeCr系磁性合金は，耐食性に優れた磁性材料とし て開発された ${ }^{1,2}$ が，高抵抗率であることから交流用の

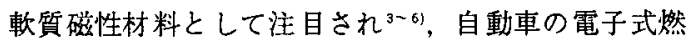
料噴射装置に尊入されているのを始めとし，応用が広 がっている。一方，焼結 FeCr系磁性合金》の実用化も 進んでいるが，材質的に高抵抗率であることに加えて， 焼結材の特徽である気孔の存在によりさらに抵抗率の 増大が生じ，交流磁気特性がさらに向上するのではな いかと考えられる。

このような状況を調べるため,さきに 3 種の $\mathrm{FeCr}$ 系合金粉末について，プレス成形圧力と焼結温度を変 化させ，それぞれ交流磁気特性に対する影響について
詳細な実験，研究を行なった81．その結果，交流磁気 特性の傾向は直流磁気特性のそれとは異なり, 優れた 交流磁気特性を得るためには，適切な成形王力および 焼結温度の選定が肝要であり，言い換えれば成形と焼 結の過程において気孔率および埊結密度の制御が重要 であるということが明らかとなった。さらにこの研究 を進めている過程において，焼結合金中に積極的に非 導電性の酸化物の添加を行なえば，一層の交流磁気特 性の向上がはかられるのではないかという発想が生ず るに至った。そのため，酸化物として $\mathrm{SiO}_{2}, \mathrm{CaO}$ 拉 び $\mathrm{Al}_{2} \mathrm{O}_{3}$ の混合物を選び, 添加効果を調べる研究を進 めたので，その結果について報告する. 
Table 1 Chemical composition of specimen

\begin{tabular}{|ccccccc|}
\multicolumn{1}{c}{} & \multicolumn{4}{c}{ Table 1 } & Chemical composition of specimen & \multicolumn{1}{c|}{ wt\% } \\
\hline C & Si & Mn & P & S & Ni & Cr \\
\hline 0.009 & 0.80 & 0.23 & 0.011 & 0.004 & 0.09 & 12.45 \\
\hline
\end{tabular}

\section{3 実験結果}

Table 2 Ratio of added oxide powder

\begin{tabular}{|ccc|}
\hline $\mathrm{SlO}_{2}$ & $\mathrm{CaO}$ & $\mathrm{Al}_{2} \mathrm{O}_{3}$ \\
\hline 62 & 24 & 14 \\
\hline
\end{tabular}

\section{2 試料および実験方法}

実験に用いた粉末の化学成分をTảble 1に示す。低 炭素で約 $12.5 \% \mathrm{Cr}$ ともに約 $0.8 \% \mathrm{Si}$ を含有しており，

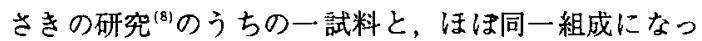
ている.この粉末に混合する非導電性酸化物としては $\mathrm{SiO}_{2}, \mathrm{AL}_{2} \mathrm{O}_{3}$ ，および $\mathrm{CaO}_{2} 3$ 種を取り上げ，その三 元状態図においてアノールサイト周辺の低融点の共晶 成分となるような混合量を選足した。それらの重量比 をTable 2 に示す．以上のように設定した酸化物粉末 をまずボールミルで混合した，次にこの酸化物粉末を， $\mathrm{FeCr}$ 合金粉末に0，0.1，0.2，0.3，0.4 および $0.6 \%$ 重 量比でそれぞれ少量のポりビニルアルコールを用いつ つ十分混合した。 これらを圧力 $4.90 \times 10^{5}$ おび $6.86 \times 10^{5} \mathrm{~Pa}$ でプレス成形した後, $133.3 \times 10^{04} \mathrm{~Pa}$ の 真空中で 30 分 $500^{\circ} \mathrm{C}$ で脱脂処理を行ない, 続いてそ れぞれ $1160^{\circ} \mathrm{C}, 1200^{\circ} \mathrm{C}, 1240^{\circ} \mathrm{C}$ おび $1280^{\circ} \mathrm{C}$ 各 温度でそれぞれ1時間の焼結を行なった。試料形状は， 外径 $45 \mathrm{~mm}$, 内径 $33 \mathrm{~mm}$, 厚 さ $6 \mathrm{~mm}$ の環状試料と, 幅 $5 \mathrm{~mm}$, 厚さ $3.5 \mathrm{~mm}$, 長さ $100 \mathrm{~mm}$ の抵抗率測定用試片 の2種である。これらにより，直流磁気測定および交 流磁気測定を行なった。また密度の測定には前者を， 抵抗率および光学顕微鏡による気孔率の測定には後者 を用いて実験を進めた，直流磁気測定には理研電子

（株）製の B-Hカープトレーサーを用い，交流磁気測 定には岩崎通信（株）製のBHアナライザーを用いた。

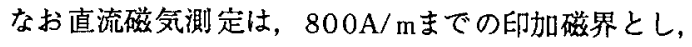

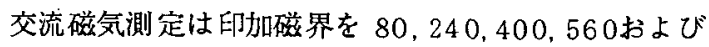
$800 \mathrm{~A} / \mathrm{m}$ の 5 段階とし，周波数を 0.5 から $200 \mathrm{kHz}$ で変化させ振幅比透磁率 $\mu$ aを求めた，また，抵抗率 は 4 端子法測定装置により測定した。合わせて光学顕 微鏡によりミクロ組織を観察し，画像処理により気孔 率の測定を行なった。

\section{1 直流磁気测定}

始めに各焼結合金について，直流状態における初磁 化およびヒステリシス曲線の測定を行なった. Fig. 1 はそのうち今回の磁気測定において，最も直流磁気特 性が優れていた成形圧力 $6.86 \times 10^{5} \mathrm{~Pa}$ ，㶹結温度 $1280^{\circ} \mathrm{C} の$ 場合における結果である。図は酸化物粉末 の添加によるそれぞれの曲線の変化を示している。ま ず，ヒステリシス曲線について見ると，酸化物粉末添 加量が增すにつれて，保磁力は增大の傾向となり，磁 束密度は曲線 1 周に渡って総体的に隇少の傾向となっ ている，また初磁化曲楾について見ると，添加量が增 大寸ると，最大透磁率は減少の傾向となっている，ま たどのプレス・焼結条件においてもほほ同様傾向の結 果となっている。

Fig. 2は添加酸化物による最大透磁率および振幅比 透磁率の変化について測定した結果の一つを示す. 図 は, 成形圧力が $6.86 \times 10^{5} \mathrm{~Pa}$, 焼結温度が $1240^{\circ} \mathrm{C} の$ 場合における測定結果で, 振幅比透磁率は, 測定の印

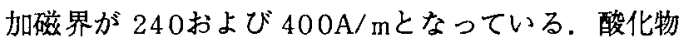
含有量が多くなるに従って明らかに少しつつ最大透磁 率および振幅比透磁率が減少している。これら特性は

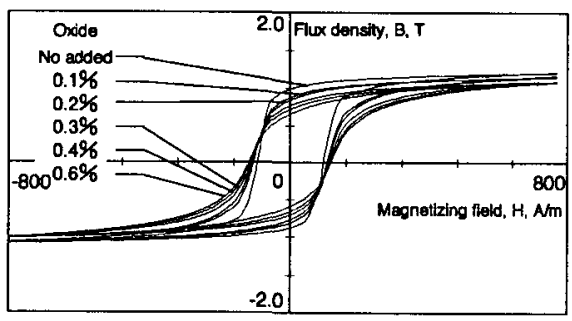

(a) Hysteresis curvo

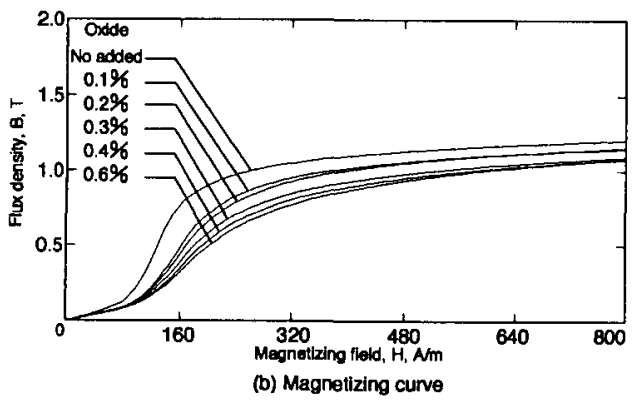

Fig. 1 Change of magnetizing and hysteresis curves (Forming pressure $6.86 \times 10^{5} \mathrm{~Pa}$, Sintering temperature $1280^{\circ} \mathrm{C}$ ). 


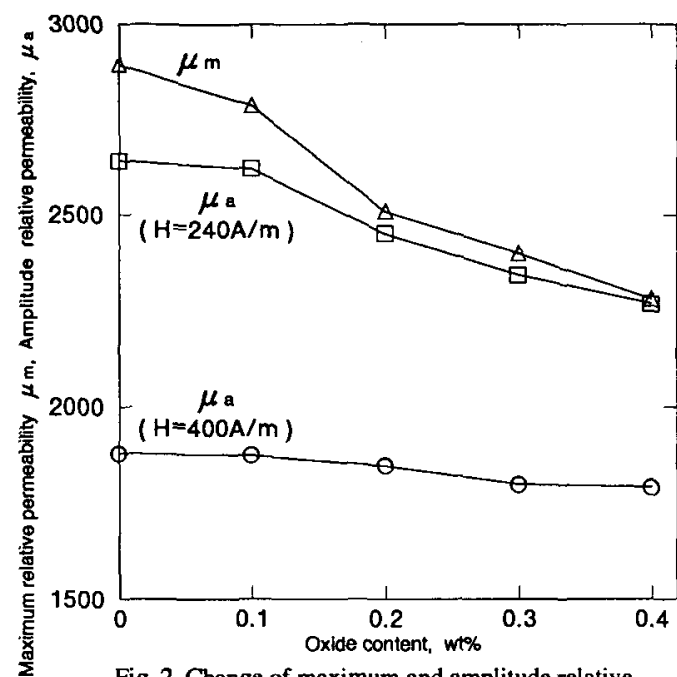

Fig. 2 Change of maximum and amplitude relative permeability with content oxide

(Forming pressure $6.86 \times 10^{5} \mathrm{~Pa}$, Sintering temperature $\left.1240^{\circ} \mathrm{C}\right)$.

種々のプレス・焼結条件においてはほ同様の傾向が得 られている。

\section{2 交流磁気特性}

続いて各焼結合金について交流状態における振幅比 透磁率の測定を行なった. Fig. 3は成形圧力 $4.90 \times$ $10^{\mathrm{s}} \mathrm{Pa}$ ，酸化物粉末添加量 $0.1 \%$ ，印加磁界 $240 \mathrm{~A} / \mathrm{m}$ の場合における，周波数による振幅比透磁率 $\mu$ aの変 化を示す、既に知られているように，給体的に周波数 の増加に伴って $\mu$ aは減少の㑯向となっている．この うち各焼結温度による変化について見ると，直流状態 (f=0)においては，焼結温度は最も离い $1280^{\circ} \mathrm{Cにお}$ いて最も特性が良く，次いで $1240^{\circ} \mathrm{C}, 1200^{\circ} \mathrm{C}$, $1160^{\circ} \mathrm{C}$ と焼結温度が低くなっていくに従い， $\mu$ aは低 下している。これに対し周波数が高くなっていくにつ れて，直流状態で最も特性の優れていた $1280^{\circ} \mathrm{C}$ 焼結 において他の焼結温度のそれよりも下回り， $f=100$ $\mathrm{kHz}$ では，直流状態では特性がむしろ少っていた $1160^{\circ} \mathrm{C} 1200^{\circ} \mathrm{C}$ 焼結の試料が良い值を示している。 他のプレス・焼結条件の試料においても同様の傾向と なった.

Fig. 4は印加磁界による振幅比透磁率の变化につい て測定した結果の一つを示す。眓は成形圧力が 6.86 $\times 10^{5} \mathrm{~Pa}$ ，焼結温度が $1240^{\circ} \mathrm{C}$ における結果で，(a)が 酸化物粉末添加なし，(b)が添加量 $0.6 \%$ となっている. 印加磁界による より $\mu \mathrm{a}$ の絶対值に差はあるものの，いずれの合金に ついても印加磁界約 $240 \mathrm{~A} / \mathrm{m}$ の付近において, 最も

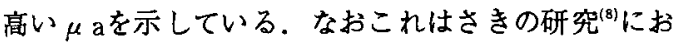

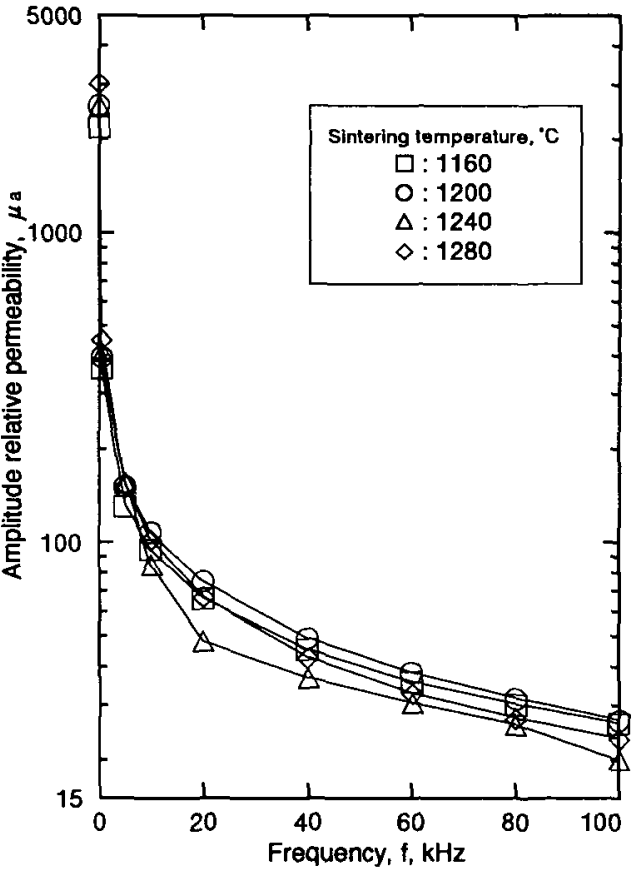

Fig. 3 Relation between frequency $f$ and amplitude relative permeability $\mu_{\mathrm{a}}$ ( Forming pressure $4.90 \times 10^{5} \mathrm{~Pa}$, Magnetizing field $240 \mathrm{~A} / \mathrm{m}$, Oxide content $0.1 \%$ ).

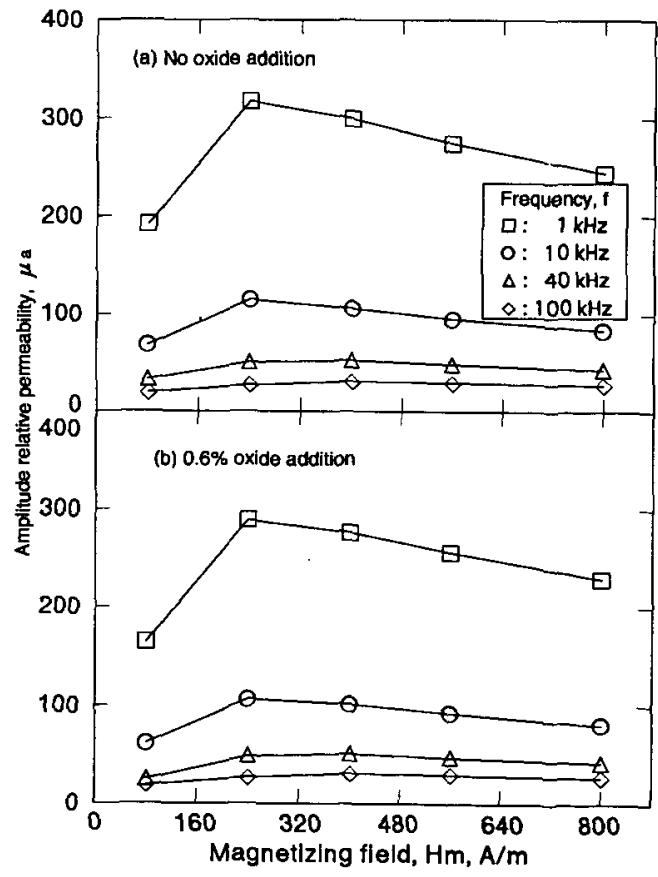

Fig. 4 Relation between magnetizing field $\mathrm{Hm}$ and Amplitude relative permeability $\mu_{\text {a }}$ ( Forming pressure $6.86 \times 10^{5} \mathrm{~Pa}$, Sintering temperature $1240^{\circ} \mathrm{C}$ ). 


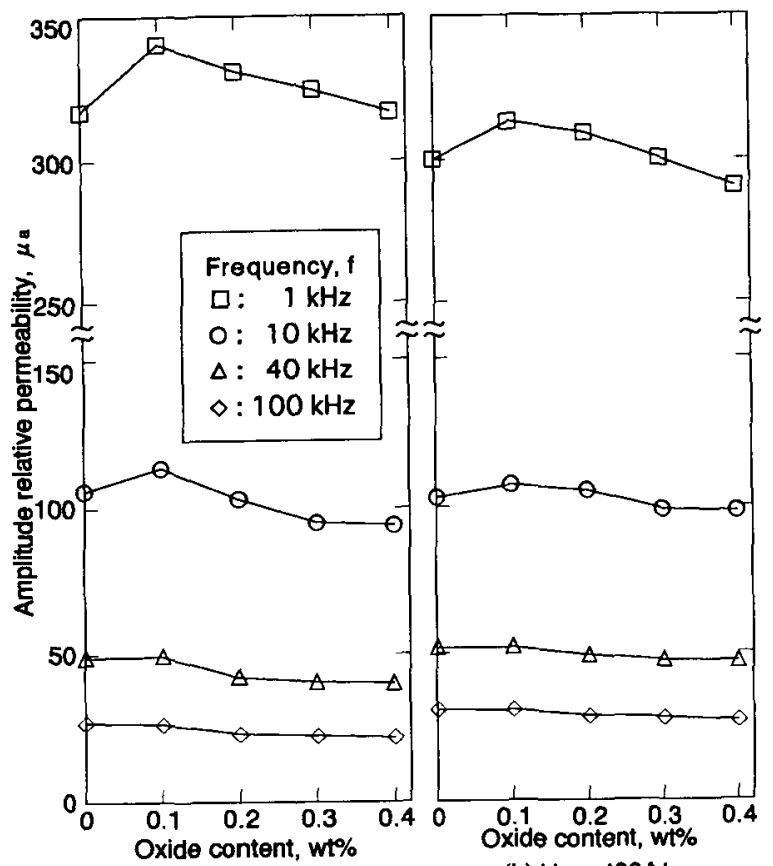

(a) $\mathrm{Hm}=240 \mathrm{~A} / \mathrm{m}$

Fig. 5 Change of amplitude relative permeability $\mu$ a with content of oxide ( Forming pressure $6.86 \times 10^{5} \mathrm{~Pa}$, Sintering temperature $1240^{\circ} \mathrm{C}$ ).

ける結果とほほ同様で，絵体的に周波数 が高くなるに従い， $\mu \mathrm{a}$ の最大值はやや高 い印加磁界の側にずれてゆくような傾向 が見られる。

Fig. 5は，酸化物粉末添加量による振幅 比透磁率 $\mu \mathrm{a}$ の変化について測定した結果 の一つを示す，図は成形㾏力が $6.86 \times$ $10^{5} \mathrm{~Pa}$ ，焼結温度が $1240^{\circ} \mathrm{C}$ 場合につい て示したものであり，(a)が印加磁界 $240 \mathrm{~A} / \mathrm{m}$ ，(b)が印加磁界 400A/mとなっ ている。図より周波数 $1 \mathrm{kHz}$ において，明 らかに添加量が $0.1 \%$ ときに最 \& $\mu$ aが 高くなり，それから添加量が增えていく に従って $\mu$ aがゆるやかに減少していくと いう現象が諗められる，10 kHzを越える とその変化は少なくなるが, 周波数が高 くなってもその傾向は残されている，給 体的に，他のプレス・焼結条件の試料に ついても，ほほ同様の傾向の変化が認め られた。

Fig. 6は焼結温度による振幅比透磁率 $\mu$ aについてまとめた結果である. 印加 磁界 $240 \mathrm{~A} / \mathrm{m}$ で，(a)が酸化物枌末添加 なし，(b)が $0.1 \%$ 添加，(c) が $0.2 \% の$ 添加の場合につ いて示している．ます，(a)添加なしの場合について 見ると，直流状態では，焼結温度が摛くなるに従い， $\mu$ aは明らかに增加の傾向となっている．しかし周波 数が高くなるに徉い逐次その傾向は逆転するようにな っている.つぎに添加量が(b) $0.1 \%$ 場合についてみ ると，直流状態では添加物なしの場合に比べ焼結温度 による增加の割合が小さくほほ同様の傾向となってい るが，交流状態になると焼結温度が $1280^{\circ} \mathrm{C}$ なった 時の $\mu \mathrm{a}$ の落ち込みが $1 \mathrm{kHz}$ において見られなくなり， また䧓波数の高いところで，添加なしのそれに比べて 落ち込みの幅が小さくなっている．添加量が(c)0.2\% となると，それらの傾向がさらに明確になっている。 3.3 焼結体特性

次に焼結体の抵抗率，密度および気孔率など焼結体 特性の測定を行いそれらの関係について調べた．

Fig. 7は焼結温度と抵抗率との関係について測定し た結果である.図は成形圧力が $6.86 \times 10^{5} \mathrm{~Pa}$ の場合 について示している，焼結温度の上年に伴い，1240 ○までは抵抗率は減少の傾向となっている。 $1280^{\circ} \mathrm{C}$ になると，ややばらつきはあるが，その減少の傾向は

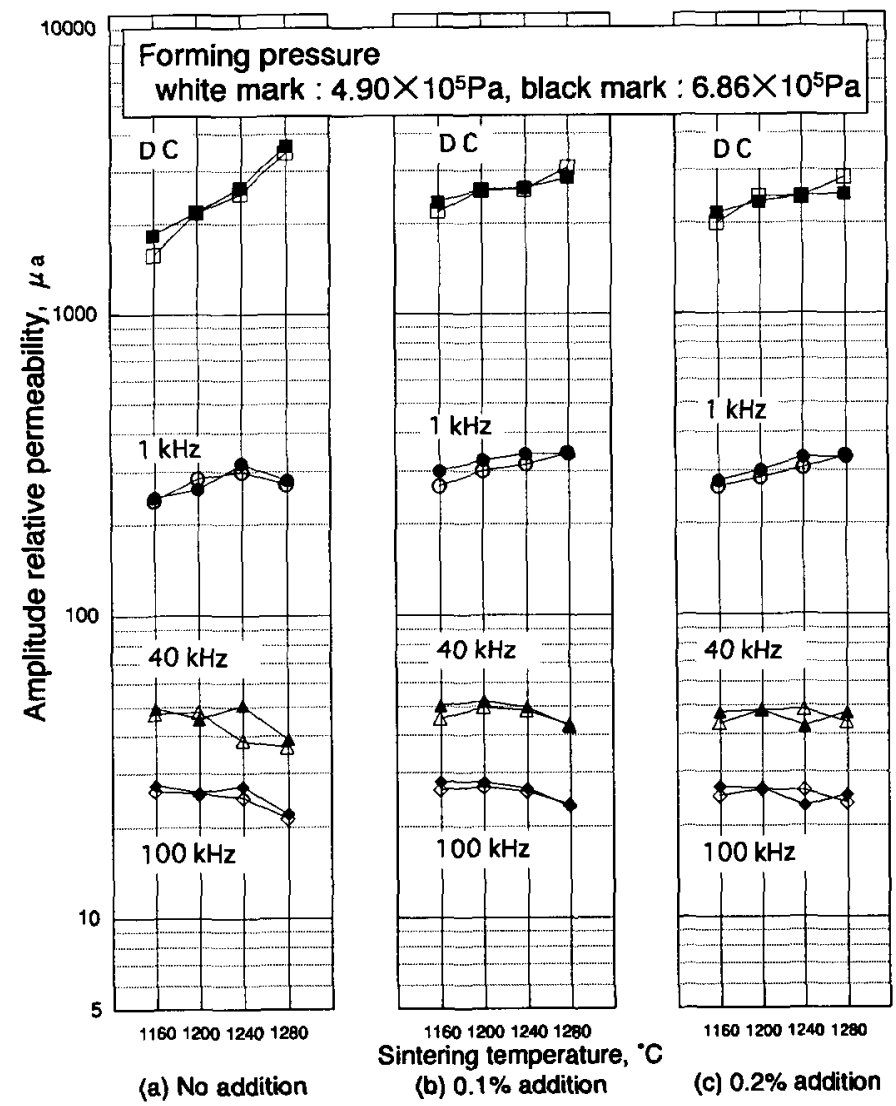

Fig. 6 Relation between sintering temperature and amplitude relative permeability $\mu$ a ( Magnetizing field $240 \mathrm{~A} / \mathrm{m}$ ). 
止まるようになっている。

Fig. 8は酸化物添加量と抵抗率との関係についてま とめた結果である。図は成形圧力 $4.90 \times 10^{5} \mathrm{~Pa}$ の場 合について示している．測定結果に若干のばらつきは あるがこの場合も焼結温度の上昇に伴いはほ抵抗率は 减少し，また添加量が增えるに従い，棇体的に抵抗率 は増加する傾向が諗められる。

Fig. 9は焼結密度と抵抗率の関係についてまとめた 結果を示す，成形圧力 $6.86 \times 10^{5} \mathrm{~Pa}$ の場合は概略焼 結密度が高く抵抗率は低い方へ，逆に $4.90 \times 10^{5} \mathrm{~Pa}$ の場合は焼結密度が低く抵抗率は高い方へ分布し，総 体的に焼結密度が高くなる程，抵抗率の減少となって

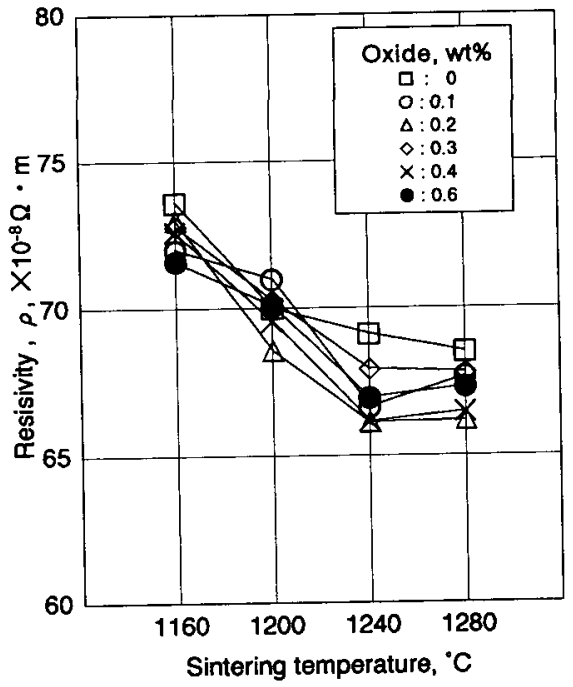

Fig. 7 Relation between sintering temperature and resistivity $\rho$ (Forming pressure $6.86 \times 10^{5} \mathrm{~Pa}$ ).

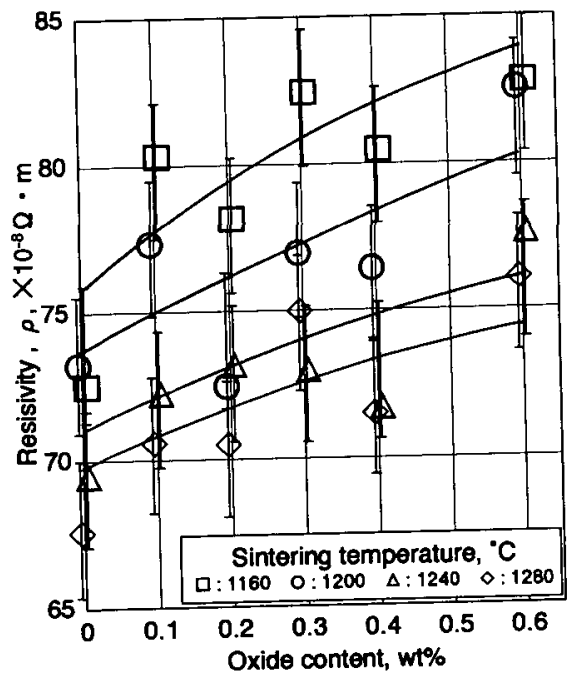

Fig. 8 Relation between oxide content and resistivity $\rho$ (Forming pressure $4.90 \times 10^{5} \mathrm{~Pa}$ ).
いる.

Fig.10は気孔率と抵抗率との関係についてまとめた 結果である。図は成形圧力が $6.86 \times 10^{5} \mathrm{~Pa}$ の場合に ついて示している，概略気孔率が増大寸ると，抵抗率 が上年する結果となっている。

\section{4 考 察}

Fig. 11 は以上の実験結果から焼結密度と振幅比透 磁率 $\mu$ aとの関係についてまとめたものである。(a)は 酸化物添加なし，(b)は $0.1 \%$ 添加，(c)は $0.2 \%$ 添加の 場合について示している．先ず，直流状態における変 化の傾向であるが，3種の添加量に共通して，焼結密 度が上昇すると $\mu$ aは增加している。 またその傾向は。

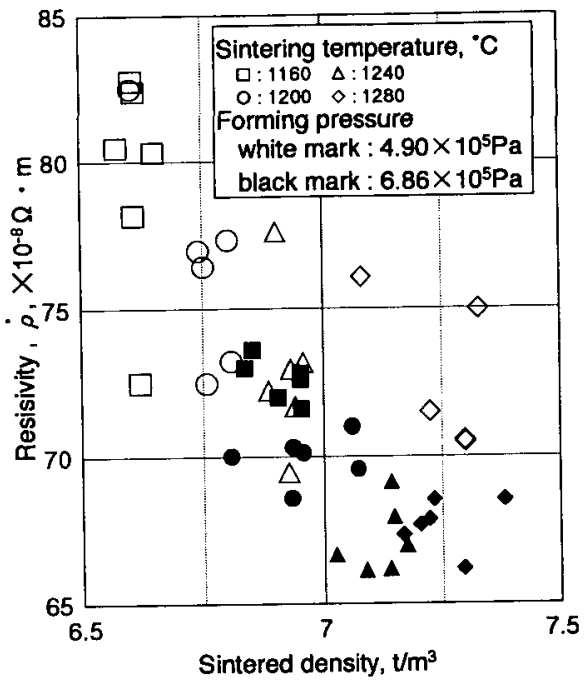

Fig. 9 Relation between sintered density and resistivity $\rho$.

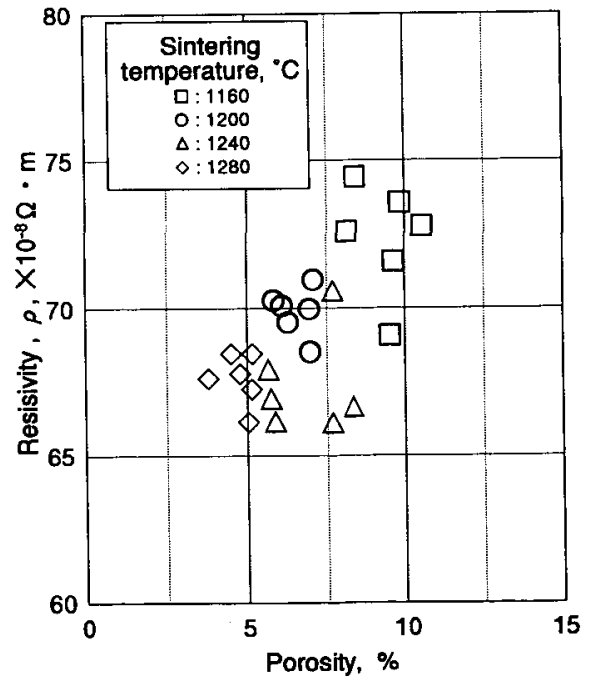

Fig. 10 Relation between porosity and resistivity $\rho$ (Forming pressure $6.86 \times 10^{5} \mathrm{~Pa}$ ). 
酸化物添加なしの場合において変化が大きくなってい る，次に交流磁気特性について見ると，直流磁気特性 の変化とは全く異なった変化の傾向となっている，先 ず，(a)添加なしの場合について見ると，周波数 $1 \mathrm{kHz}$ において焼結密度が約 $7.0 〜 7.2 \mathrm{t} / \mathrm{m}^{3}$ のあたりで $\mu$ aが 最も离くなり，それ以上の烍結密度ではむしろ特性が 悪くなることが認められ，さらに周波数が高くなると その傾向は顕著となっている，さらに (b) $0.1 \%$ 添加の 場合について見ると，周波数が $1 \mathrm{kHz}$ の場合には，(a) の場合に見られたような高密度側における $\mu$ aの落ち 込みが認められない．また $40 \mathrm{kHz}$ 以上になってもその 傾向が残り， $\mu \mathrm{a}$ の落ち込みの幅は，(a)の場合に比べ て小さくなっている. (c) $0.2 \%$ 添加の場合は，この変 化の傾向がさらにはっきり表われるようになっている.

Fig. 12 は印加磁界 $400 \mathrm{~A} / \mathrm{m}$ の場合における周波数

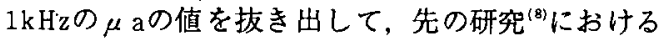
$\mathrm{Fe}-12.5 \mathrm{Cr}$ との比較を行なった結果である. 図より， $\mu$ aの值はどちらも 7.0〜 7.2t/m触のあたりで最も高く なっているが，その值は酸化物を添加した今回の実験

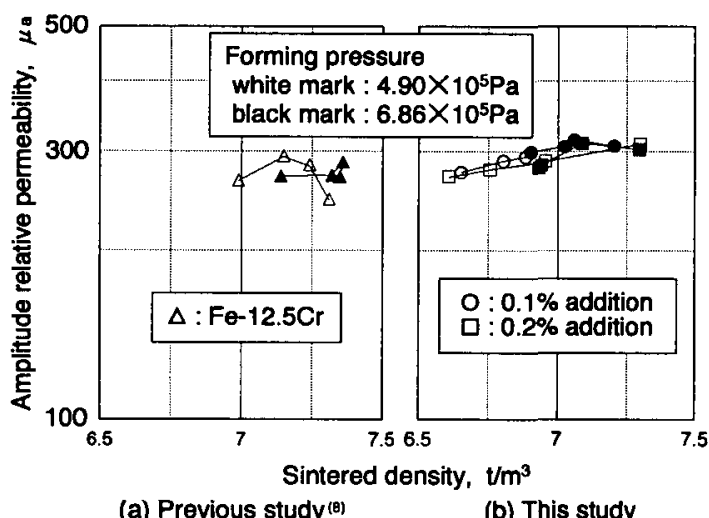

(a) Previous study(e)

(b) This study

Fig. 12 Comparison of previous study and this study in relation between amplitude relative permeability $\mu_{\mathrm{a}}$ and sintered density (Magnetizing field $400 \mathrm{~A} / \mathrm{m}$, Frequency $1 \mathrm{kHz}$ ).

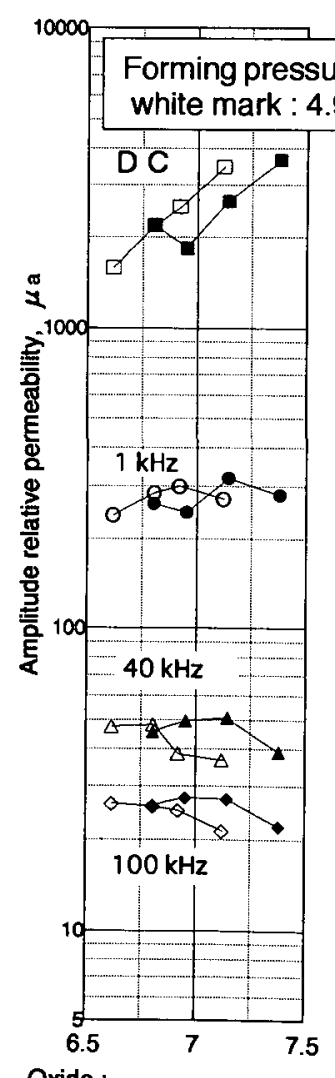

(a) No addition

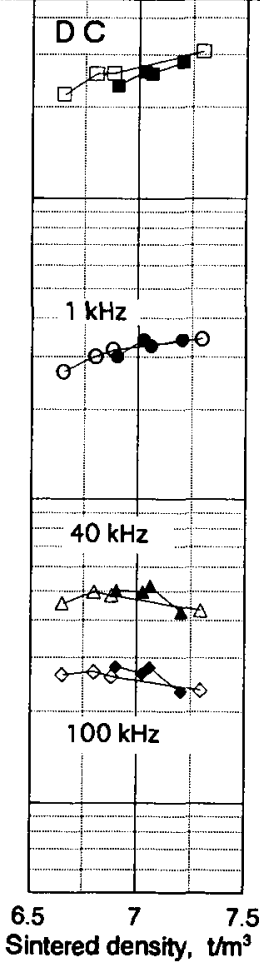

(b) $0.1 \%$ addition

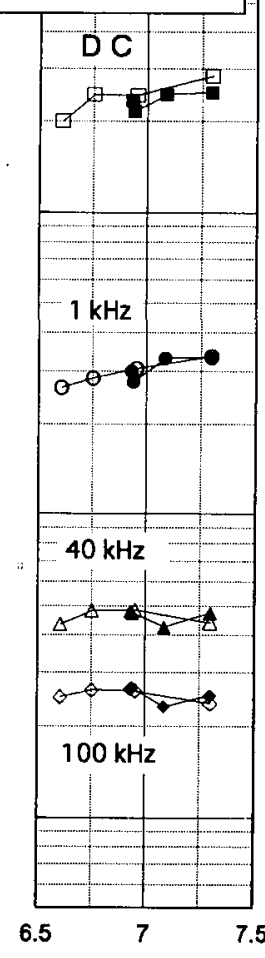

(c) $0.2 \%$ addition

Fig. 11 Relation between sintered density and amplitude relative permeability $\mu$ a (Magnetizing field $240 \mathrm{~A} / \mathrm{m}$ ).

においては周波数 $1 \mathrm{kHz}$ の振幅比透磁率が 300 を越え 明らかに上回っている。

ついで気孔率と振幅比透磁率 $\mu$ a との 関係について考察してみると，気孔率と 抵抗率とは Fig.10において示された通り， ほは相関の関係にあることから，さきの 焼結密度による変化とほほ逆傾向の変化 を示した，気孔率の上昇に伴い，直流お

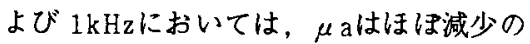
傾向となっている。また周波数が上がる につれて，気孔率約 6.0\%付近のところ までは $\mu$ aが上昇し，それ以上では安定 して殆ど変化が見られなくなった。

Fig. 13 は抵抗率と振幅比透磁率 $\mu$ a の関係についてまとめた結果を示す。ま ず直流磁気特性について見ると，(a)，(b) および(c)の結果に共通して，抵抗率が增 加するに従って $\mu$ aは減少の傾向となっ ている. Fig. 9およびFig.10にみられ るように，抵抗率は焼結密度および気孔 率と密接な関係があるため，それらによ る影響が主に現われているということが できる，交流磁気特性については，酸化 物を添加した場合と，そうでない場合に おいて，明らかに傾向の相違がみられ る.酸化物なしの場合には，周波数が 40 および 100kHzにおいて，ほほ 67 $70 \times 10^{-8} \Omega \cdot \mathrm{m}$ の範囲で $\mu \mathrm{a}$ は上昇の傾向 


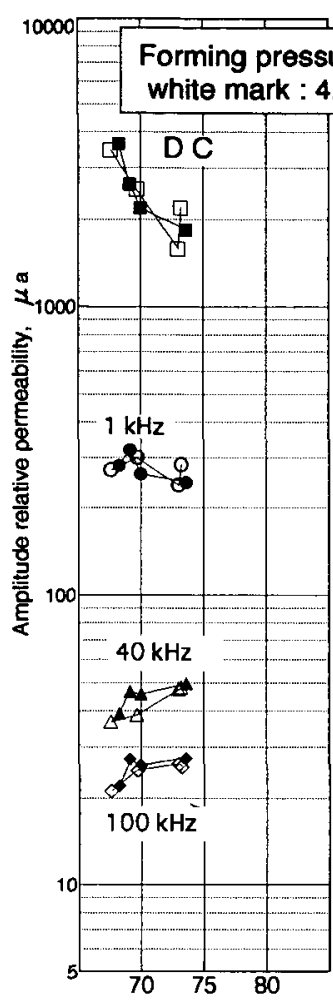

(a) No addition

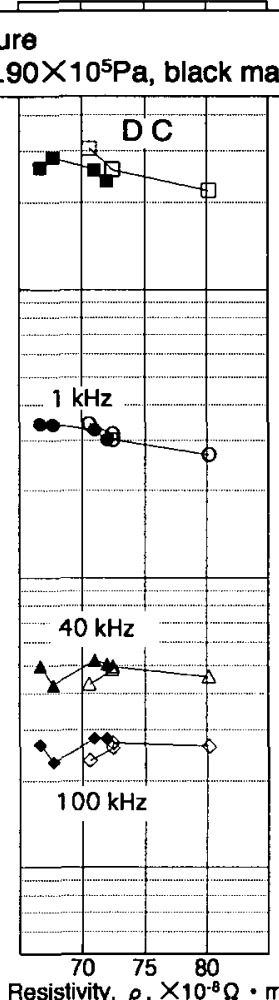

(b) $0.1 \%$ addition
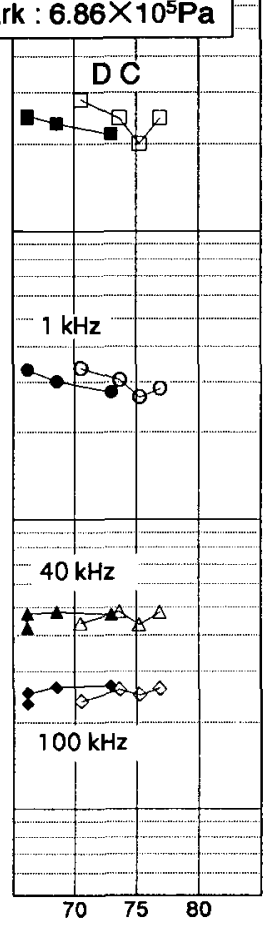

(c) $0.2 \%$ addition

Fig. 13 Relation between resistivity and amplitude relative permeability $\mu$ a ( Magnetizing field $240 \mathrm{~A} / \mathrm{m}$ ).

をみせ， $70 \times 10^{-8} \Omega \cdot \mathrm{m}$ 以上では增加が少なくなって いる.それに対し，酸化物を添加した場合では，周波 数が 40 および $100 \mathrm{kH}$ において，抵抗率が変化して \&， $\mu$ aの変化は少なく留まっている。

これらの結果より， FeCr磁性合金において，交流 磁気特性の向上に少量の酸化物粉末の添加が有効であ ることが知られる。

\section{5 総括および結言}

$\mathrm{Fe}-12.5 \mathrm{Cr}$ 合金粉末に $\mathrm{SiO}_{2}, \mathrm{CaO} よ ひ ゙ \mathrm{Al}_{2} \mathrm{O}_{3}$ の混 合酸化物粉末を添加し, 成形圧力および焼結温度を変 化して交流磁気特性を測定する実騟研究を行ない，焼 結密度, 気孔率,抵抗率等焼結特性との関係について

\section{考察した。}

(1) 直流磁気特性は，体的に焼結温度が上 昇すると，単調に向上するが，酸化物粉末添 加量が增していくにつれてその特性は低下の 傾向となった。

（2）これに対し交流の振幅比透磁率は, 焼結 温度が1200 1240付近まで上昇し，それ 以上において低下するという傾向を示すが， 酸化物粉末の添加により，その低下の割合が 小さくなることが認められる，また，酸化物

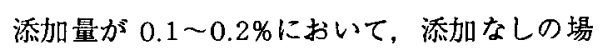
合における振幅比透磁率を上回るようになっ た.

(3)以上のように，FeCr系焼結磁性合金にお いて優れた交流磁気特性を得るために，酸化 物粉末の添加は有効な手段であることを確認 することができた。

最後に，本研究において実験に協力された 大同工業大学電気工学科, 尾烟智光氏,なら びに学生, 吳栓所, 栗原潤一の両君に厚く感 謝申しあげる。

\section{文献}

(1) 加藤, 関尾, 草加：電気整鋼，41(1970)， 127 .

（2）加藤, 関尾：電気製鋼，42(1971)，41.

（3）加藤，高瀨，大岛：電気製鋼，64(1993)，252.

（4）加藤, 吉野, 大島, 尾畑: 大同工業大学紀要, 30(1993), 未刊.

(5) T.Kato, H. Tak ase, Y.Ohs hima, S. Yah agi : 3rd Japan In ternational SA MPE Sy mosi um,E-4-7 (1993).

（6）加藤，吉野，金沢，大岛，矢萩：日本応用磁気 学会誌, 18(1994), 投稿中.

（7）加藤(哲), 一草加, 加藤(俊)：電気製鋼，48

(1977), 144.

（8）加藤，河野，川村，中島：粉体および粉末冶金, 40(1993), 1246. 